\title{
THE ENGINEER AND THE CONSERVATION OF NATURAL RESOURCES
}

$I^{\mathrm{T}}$ $T$ has now become a truism that the history of man's achievement has been his constant effort to master the forces of Nature and the tremendous resources that are his inheritance. But in his endeavour to fulfil this aspiration, which has never beon entirely realized, man has disturbed the delicate balance maintained by Nature in guarding her resources and has created the problem of conservation of these natural resources, the depletion of which is, in some quarters, a matter of growing concern. Such was the subject of the first Graham Clark Lecture, delivered to the Institution of Civil Engineers on May 4 by Sir Harold Hartley. The Lecture is given in honour of the late Graham Clark, who for many years was secretary of the Institution and who strove to promote co-operation between engineering societies both in Britain and abroad; after paying a brief tribute to him, Sir Harold turned to the main topic of his address, a subject which, while it has been dwelt upon previously in one way or another, he approached from a novel direction in stressing the importance of the engineer in contributing to the conservation of the great bounty of Nature.

The greatest resources upon which our civilization depends are soil and water, and Nature has always jealously guarded these and maintained her equilibrium therein; but man, when he appeared on the scene, upset this by the clearing of land for cultivation and dwellings, creating, as a result, problems of conserving these two most valuable resources. Irrigation and storage schemes have constituted one attempt to meet these problems, from the groat systems of the ancient empires to the tremendous multi-purpose projects of to-day, embodying the storage of water for irrigation, hydroelectric power, flood control and transportation, such as the Tennessee Valley Authority Plan. Such facilities as improvements in dam and canal construction, the use of hydraulic models, geophysics and soil mechanics have aided the solution of many problems; but the inexorable forces of Nature are always at work, and man is reminded of this by the appearance of new difficulties such as the silting up of reservoirs or increasing salinity in irrigation systems by lack of sufficient water. In some areas shortage of water is a grave problem, and the future of water supplies is dependent on the wider acceptance of such techniques as the re-use of water by the treatment of sewage and effluents, or the distillation of sea water, added to which is needed a more thorough knowledge of the behaviour of ground water. Again, where land is valuable, coastal and inland erosion are boing curtailed and land is being reclaimed from sea and marsh as in Holland and in the Fens in Britain. In all these efforts, the main problem is to maintain cultivation without loss of fertility in the soil, and in this regard we are gradually learning how to make uso of Nature's gifts.

Sir Harold went on to remark that, next to soil and water, energy forms the greatest need of mankind; the consumption of energy per capita determines the standard of living of a country. Here the engineer's role is to increase the efficiency of combustion devices and so effect a saving of such sources of energy as coal and petroleum products, since these provide mankind with a tremendous amount of energy; but with the advent of nuclear power man will be able to utilize these more for their chemical potentialities than before.

The conservation of raw materials and their economical use form one of the engineer's most notable contributions to-day. New methods of treating raw materials, such as the economic recovery of low-grade ores, have advanced greatly during the past two decades. In the field of structural engineering, a saving of steel has been effected by the increasing use of concrete and by new concepts of structural analysis, such as the plastic method of design, developed in the Engineering Department at Cambridge, with the advance of new structural steel forms. Improvements in the working of metals and developments in lubricants and anti-corrosives have resulted in further economies. Finally, there is the greatest economy of all, that of human labour by the use of automatic control and the possibilities of the automatic factory; here Sir Harold directed attention to the fact that, while control engineering is making great advances abroad, more recognition needs to be shown in Britain in this field.

In his closing remarks, Sir Harold drew three important conclusions : first, progress needs specialization, coupled with a wide outlook and a knowledge of other fields of endeavour, for too much specialization is dangerous. Secondly, we must work more closely with Nature in a new partnership made possible only with the great forces that she encompasses. Finally, there is in each generation a limit to what is possible, and it is imposed by the resources and skills which are available to man and which, with their uneven distribution, must be used to their best advantage with careful planning, for our convenience.

One may feel inclined to think of this Lecture as a catalogue of attainments, but it was, in fact, more than that; it was a timely warning. While man has a croditable record of achievement to look back upon, he still has to come to work more with Nature, for he cannot control her. Only then will he be able to use and enjoy the great endowment of her resources which has come to be his heritage.

\section{E. T. Honmgren}

\section{TOWNS AND THEIR HINTER- LANDS}

CINCE its inception in 1941, the Research Maps $\checkmark$ Office of the Ministry of Town and Country Planning, now part of the Ministry of Housing and Local Government, has carried through a remarkable programme of work. In particular, it has prepared with the joint sponsorship of the Department of Health for Scotland the now extensive series of National Planning maps on the uniform scale of $1: 625,000$, or approximately ten miles to the inch, each in two sheets covering England, Wales and Scotland. Civil servants work in anonymity; but it is not difficult to detect the skill and care of the guiding hand of Dr. E. C. Willatts, who has been in charge of the work for most of the past fourteen 